\title{
Expression of Enamel Proteins in Human Dental Pulp Stem Cells by the Effect of extracellular Matrix
}

\author{
Expresión de Proteínas de Esmalte en Células Madre de \\ Pulpa Dental Humana por el Efecto de Matriz Extracelular
}

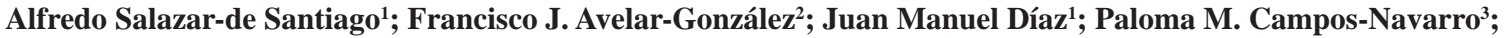
Elizz M. Flores-Villalpado ${ }^{1}$; Edgar E. Hernández-Cuéllar ${ }^{1}$ \& Alma L. Guerrero-Barrera ${ }^{1}$
\end{abstract}

SALAZAR-DE SANTIAGO, A.; AVELAR-GONZÁlez, F. J.; DÍAZ, J. M.; CAMPOS-NAVARRO, P. M.; FLORESVILLALPADO, E. M.; HERNÁNDEZ-CUÉLLAR, E. E. \& GUERRERO-BARRERA, A. L. Expression of enamel proteins in human dental pulp stem cells by the effect of extracellular matrix. Int. J.Morphol., 38(6):1742-1750, 2020.

SUMMARY: Mesenchymal stem cells are present in adult tissues such as the human dental pulp. They are pluripotent and can differentiate into various specialized cell types in vitro through appropriate stimuli. Ameloblasts produce human tooth enamel only during embryonic development before tooth eruption, so endogenous regeneration is not possible. Various efforts have been aimed at generating natural or artificial substitutes for dental enamel with properties similar to the specific components of said tissue. The purpose of this study was to induce human dental pulp stem cells to produce enamel proteins using extracellular matrix derived from the rat tail tendon and pigskin. Primary cultures of human dental pulp stem cells were established and characterized by RT-PCR and immunofluorescence, using mesenchymal cell markers such as CD14, CD40, CD44, CD105, and STRO-1. The cells were then incubated with the extracellular matrix for fourteen days and labeled with specific antibodies to detect the expression of dental enamel proteins such as amelogenin, ameloblastin, enamelisin, tuftelin, and parvalbumin, characteristics of the phenotype of ameloblasts. This work demonstrated a positive effect of the extracellular matrix to induce the expression of enamel proteins in the stem cells of the human dental pulp.

KEY WORDS: Stem cells; Dental pulp; Extracellular matrix; Tissue engineering; Dental enamel.

\section{INTRODUCTION}

Mesenchymal stem cells (MSCs) are non-specialized cells that have the capacity of self-renewal and differentiation into other cell types. They are present in several adult tissues such as skin, adipose tissue, peripheral blood, bone marrow, pancreas, bowels, brain, hair follicles and dental pulp (Potdar $\&$ Jethmalani, 2015). These cells are an attractive supply for tissue engineering due to their differentiation versatility to obtain osteoblasts, chondrocytes and adipocytes, among other cell types (Núñez-Toldrà, et al., 2017). Human dental pulp stem cells (hDPSCs) are an important source of MSCs, with a wide potential application in reconstruction, regenerative therapy and tissue repair. The pluripotential properties of hDPSCs allow their differentiation to cells from any fundamental embryonic layer (Singh et al., 2016) such as odontoblasts, osteoblasts, adipocytes, chondrocytes, osteocytes, nerve cells, hepatocytes, cardiomyocytes, epithelial corneal cells, melanocytes and insulin producing cells, making the regeneration of new organic tissues possible (Bonato et al., 2017; Benício et al., 2018). The most mineralized tissue in the human body is the dental enamel (Patel \& Preedy, 2017). The dental enamel is formed by ameloblasts derived from the ectoderm, which are induced through diverse molecules present in the surrounding extracellular matrix (ECM). The differentiation in ameloblast is characterized by the expression of different proteins such as amelogenin, enamelisin, ameloblastin and tuftelin, as well as proteinases, among others, all constituents of the enamel matrix. Thus, the ECM plays an important role in cell differentiation processes by regulating cellular behavior, development, migration, proliferation and maintenance of

\footnotetext{
${ }^{1}$ Laboratorio de Biología Celular y Tisular, Universidad Autónoma de Aguascalientes, México.

${ }^{2}$ Laboratorio de Estudios Ambientales, Universidad Autónoma de Aguascalientes, México.

${ }^{3}$ Laboratorio de Histología, Facultad de Estomatología, Universidad Autónoma de San Luis Potosí, México.

The research was funded by PRODEP of the Federal Government of Mexico, scholarship No. UAZ-399/ 511-6 / 17-6885. Likewise by the Autonomous University of Aguascalientes through the Special Resource for Research in 2017 and 2018 and with resources from Social Impact Projects.
} 
SALAZAR-DE SANTIAGO, A.; AVELAR-GONZÁLEZ, F. J.; DÍAZ, J. M.; CAMPOS-NAVARRO, P. M.; FLORES-VILLALPADO, E. M.; HERNÁNDEZ-CUÉLLAR, E. E. \& GUERRERO-BARRERA, A. L. Expression of enamel proteins in human dental pulp stem cells by the effect of extracellular matrix. Int. J.Morphol., 38(6):1742-1750, 2020.

cellular phenotypes (Fukumoto \& Yamada, 2005; Chiego, 2014). The aim of the present study was to stimulate hDPSCs with two different sources of ECM to induce the expression of amelogenin, enamelisin, ameloblastin, parvalbumin and tuftelin and contribute to studies in the area of tissue engineering for the exogenous production of tooth enamel.

\section{MATERIAL AND METHOD}

Primary cell culture isolation. All the clinical and experimental procedures performed in this study were approved by the Institutional Bioethics Committee of the Autonomous University of Aguascalientes, Mexico CIB-UAA-20, in accordance with the principles expressed in the Declaration of Helsinki. Informed consent was applied for all experiments. The dental human pulp was obtained from nonerupted third molars extracted by therapeutic indication from 10 donors of both sexes between 16 and 24 years old at the Clinic in the Biomedical Unit of the Autonomous University of Aguascalientes. The dental pieces obtained were washed in $0.9 \%$ saline solution containing $1.2 \mathrm{mg} / \mathrm{ml}$ of Clindamycin and transported at $4^{\circ} \mathrm{C}$ in Dulbecco's Modified Eagle's Medium (DMEM) (Gibco®, USA), supplemented with $15 \%$ fetal bovine serum (FBS) (Gibco®, USA), $1 \%$ of antibiotics Penicillin- Streptomycin (Gibco®, USA), and $1 \%$ Amphotericin B (Gibco®, USA). The hDPSCs obtention was carried out under sterile conditions. Dental pieces were washed 3x with PBS (Gibco®, USA) supplemented with antibiotics. Pulp tissue was removed by cutting the clinical crown at the level of the amelo-cemented junction. The exposed pulp tissue was extracted using root canal files and macerated into portions of about $1 \mathrm{~mm}^{3}$ and digested with $2 \mathrm{mg} / \mathrm{ml}$ of EDTA (Affymetrix, USA) for 10 minutes at $37{ }^{\circ} \mathrm{C}$. After that, samples were centrifuged at $1000 \mathrm{x}$ g for 5 minutes and were incubated with $333 \mathrm{mg} / \mathrm{ml}$ of Collagenase Type I (Gibco®, USA) for 30 minutes and finally were centrifuged at $1000 \mathrm{x} g$ for 5 minutes. The pellet was resuspended in complete media containing DMEM/15\% FBS and antibiotics. Finally, the cells were seeded on 35 mm culture dishes and incubated at $37{ }^{\circ} \mathrm{C}$ in $5 \% \mathrm{CO}_{2}$ until reaching more than $80 \%$ of confluence in 28 days. The culture medium was changed 2 times per week. The cell proliferation test was made by vital dye exclusion assay. Confluent cell culture dishes were treated with $500 \mathrm{ml}$ TrypLE ${ }^{\mathrm{TM}}$ Express 1X (Gibco®, USA) and incubated for 10 minutes at $37^{\circ} \mathrm{C} / 5 \% \mathrm{CO}_{2}$. The enzymatic disaggregation reagent was inactivated using complete media. The cell counting was made by hemocytometer using $0.4 \%$ Trypan Blue (Gibco®, USA). The above procedure was performed until reaching the cell passage number 3 . The cell cultures were observed using an optical microscope (Zeiss, Primo star) and images were captured by AmScope software (Version: x64, 3.7.7303).

MTT cell proliferation assay. To validate the vital dye exclusion method, MTT assay was used (Roche, Germany) according to the manufacturer's instructions. Dental pulp cells were seeded in 96-wells plate by triplicate and incubated at $37^{\circ} \mathrm{C} / 5 \% \mathrm{CO} 2$. The cell viability was measured every $24 \mathrm{~h}$ for a total of $120 \mathrm{~h}$ and the absorbance was quantified by Bio-Rad Microplate Reader Benchmark (Bio-Rad, USA) with a $570 \mathrm{~nm}$ filter.

Immunophenotyping. The pluripotential nature of dental pulp cells was assessed by immunofluorescence, using the following antibodies Anti-CD40 Human (Mouse) Fluorescein Conjugate (Calbiochem ${ }^{\circledR}$, USA) dilution: 1:10, FITC Mouse Anti- Human CD44, (BD Pharmingen ${ }^{\mathrm{TM}}$, USA) dilution: 1:20 and PE Mouse anti-Human CD105, (BD Pharmingen ${ }^{\mathrm{TM}}$, USA) dilution: 1:6. Cells at 4th passage were seeded in 8-wells Lab-Tek Chamber Slide w/Cover Permanox Slide Sterile (Thermo-Scientific, USA). Confluent cells were fixed with $3.7 \%$ formaldehyde for 30 minutes. Nonspecific binding sites were blocked with $1 \%$ bovine serum albumin (BSA) (Sigma Life Science, USA) for 30 minutes and washed $3 x$. Samples were then incubated with antibodies respectively for $12 \mathrm{~h}$ at $4^{\circ} \mathrm{C}$ and protected from light. Then samples were counterstained with Hoechst 33342 (Molecular Probes, USA) at $2 \mathrm{mg} / \mathrm{ml}$ for 15 minutes. Finally, the samples were mounted with ProLong Gold (Thermo Fisher Scientific $^{\mathrm{TM}}$, USA). Images were obtained using a confocal LSM700 Carl Zeiss Axio Observer Z1 Inverted Microscope; Objective: ECPlnN 40x/1.3 Oil DICIII, at a resolution of $0.26 \mathrm{~mm}$; Optovar 1x; Tot. Mag. 400x, being processed in the software ZEN Black 2.3 SP1. Likewise, analysis of the expression of mesenchymal genes was performed by retrotranscription and PCR. Total RNA was isolated from 5 samples of dental pulp cells, using the TRIzol isolation reagent (Carlsbad, USA) according to the manufacturer's protocol and taking as a reference to the study of Núñez-Toldrà et al. Complementary DNA synthesis (cDNA) was obtained by the reverse transcriptase reagent (MultiScribe ${ }^{\mathrm{TM}}$, USA). The PCR was performed in an Applied Biosystems Veriti 96 Well Thermal Cycler (ThermoFisher, USA). The cDNA obtained was loaded on $1.6 \%$ agarose gel and labeled with ethidium bromide (EtBr) at $0.5 \mathrm{mg} / \mathrm{ml}$. The oligonucleotides used for PCR assay are shown in Table I. The GAPDH was used as a housekeeping gene. All analyses were performed by triplicate.

Extracellular Matrix gel obtention and cell stimulation process. The Extracellular Matrix Gel (EMG) used in this work was obtained from pigskin and rat tail tendon. The research protocol for conducting animal experiments was 
SALAZAR-DE SANTIAGO, A.; AVELAR-GONZÁLEZ, F. J.; DÍAZ, J. M.; CAMPOS-NAVARRO, P. M.; FLORES-VILLALPADO, E. M.; HERNÁNDEZ-CUÉLLAR, E. E. \& GUERRERO-BARRERA, A. L. Expression of enamel proteins in human dental pulp stem cells by the effect of extracellular matrix. Int. J.Morphol., 38(6):1742-1750, 2020.

Table I. Oligonucleotides used in this study to value the mesenchymal origin of human dental pulp stem cells.

\begin{tabular}{lclc}
\hline CDs/Gene Name & Gene ID & Primer Sequence & Product size (bp) \\
\hline CD14 & 929 & $\begin{array}{l}\text { F: GACCTAAAGATAACCGGCACC } \\
\text { R: GCAATGCTCAGTACCTTGAGG }\end{array}$ & 161 \\
CD34 & 947 & $\begin{array}{l}\text { F: CACAGGAGAAAGGCTGGG } \\
\text { R: CGTGTTGTCTTGCTGAATGG }\end{array}$ & 179 \\
CD44 & 960 & $\begin{array}{l}\text { F: CAACACAAATGGCTGGTACG } \\
\text { R: GTGTGGTTGAAATGGTGCTG }\end{array}$ & \multirow{2}{*}{153} \\
STRO-1 & 683 & F: CAGGCACTCTATTCCCAGAG \\
& R: TCTGTCGACACCAGCTCAAG & 149 \\
GAPDH & \multirow{2}{*}{2597} & $\begin{array}{l}\text { F: ACAGTTGCCATGTAGACC } \\
\text { R: TTTTGGTTGAGCACAGG }\end{array}$ & 244 \\
\end{tabular}

approved by the Institutional Bioethics Committee of the Autonomous University of Aguascalientes, Mexico CIBUAA-20. For the pigskin sample, $5 \times 5 \mathrm{~cm}$ of skin was obtained immediately after slaughtering and washed $2 \mathrm{x}$ with distilled water $2 \%$ of iodine. The subcutaneous fat was removed and cut into pieces of $50 \mathrm{~mm}$, this protocol is made to obtain extracellular matrix. The rat tail tendon matrix was obtained from sacrificed Wistar rats, the protocol is made to obtain type I collagen. Tail skin and subcutaneous tissue were separated to obtain the tail tendon. Samples were processed through an acid method (Yang \& Shu, 2014), placing the tissues in $2.5 \%$ of acetic acid/distilled water (v/v) under magnetic stirring incubation at $100 \mathrm{rpm}$, overnight. The suspension was filtered through filter paper and stored at $4{ }^{\circ} \mathrm{C}$. Quantification of proteins in the samples were performed by Bradford assay, and the absorbance was measured at $595 \mathrm{~nm}$. To determine the concentration of proteins in the EMG, the measurements were overlapped with a standard linear curve. To induce the enamel proteins production from hDPSCs in vitro, the cell culture plates were pre-treated by EMG from pigskin or rat tail. The matrix gel was placed on the culture plates and incubated at $37^{\circ} \mathrm{C} / 5 \%$ $\mathrm{CO}_{2}$ for two weeks. Before seeding the hDPSCs, the $\mathrm{pH}$ of cell culture media was adjusted to 7.4 and $1 \times 10^{6}$ of hDPSCs in passage 4 were seeded in pre-treated plates. The cells were incubated in complete media at $37^{\circ} \mathrm{C} / 5 \% \mathrm{CO}_{2}$ for 14 days, replacing the cell culture medium $2 x$ per week until reaching $\sim 80 \%$ of confluence.
Detection of dental enamel proteins. The enamel proteins detection such as amelogenin, ameloblastin, enamelisin, tuftelin and parvalbumin in the hDPSCs treated with the extracellular matrix gel was performed using immunofluorescence assay. The hDPSCs previously treated, were seeded in 8-well Lab-Tek chambers. The samples were fixed using $3.7 \%$ formaldehyde and incubated at $37^{\circ} \mathrm{C}$ for 30 min. After incubation, the cells were washed $3 x$ with PBS and nonspecific binding sites were blocked with $1 \%$ bovine serum albumin (BSA) (Sigma Life Science, USA) for 30 minutes. For the detection of enamel proteins, the samples were incubated overnight at $4{ }^{\circ} \mathrm{C}$ with the primary antibodies listed in Table II. This was followed by incubation of the secondary antibodies with Alexa Fluor 488 goat anti-rabbit (Molecular Probes, USA) dilution 1:800 and Alexa Fluor 594 goat anti-rabbit (Molecular Probes, USA) dilution 1:800. All samples were nuclear counterstained and mounted. Images were obtained by Confocal Microscope. The controls in this experiment were established with hDPSCs without differentiation treatment.

Statistical analysis. Graph Pad Prism 7.0 was the software used in this study to validate the quantitative data. All the experiments were performed by triplicate and the plots show the averages and standard deviations. The presence of statistically significant differences $(p<0.05)$ in the MTT assay results were analyzed and compared with their controls using the Tukey's multiple comparison test.

Table II. Information about primary antibodies and the dilution used for detection of enamel proteins.

\begin{tabular}{llc}
\hline Enamel Protein & \multicolumn{1}{c}{ Primary antibody } & Dilution \\
\hline Amelogenin & Anti-AMELX. Rabbit polyclonal. ABCAM, USA & $1: 25$ \\
Enamelisin & Anti-MMP20 [EP1275Y]. Rabbit monoclonal ABCAM, USA & $1: 25$ \\
Parvalbumin & Parvalbumin. Rabbit polyclonal. Invitrogen, USA & $1: 25$ \\
Tuftelin & TUFT1. Rabbit polyclonal. Invitrogen, USA & $1: 100$ \\
Ameloblastin & Ameloblastin (H300). Rabbit polyclonal. Santa Cruz Biotechnology, USA & $1: 200$ \\
\hline
\end{tabular}




\section{RESULTS}

Primary cell culture isolation. The results obtained, showed that from the dental pulp tissue of human third molars and with the method of enzymatic digestion, it was possible to isolate individual cells and colonies after a cell culture period of 28 days. The cells obtained showed a starry, elongated and extended appearance, with fibroblast-like or spindleshaped polygonal contours, bipolar and grouped into colonies in cell culture. As for their cytoplasm, they had a homogeneous appearance with cytoplasmic projections that allowed them to communicate with each other, with a large spherical or ovoid nucleus, with thin and slightly granular chromatin and one or more nucleoli were evident (Fig. 1A). This morphology and proliferation patterns were maintained even when the confluence was reached (Fig. 1B).

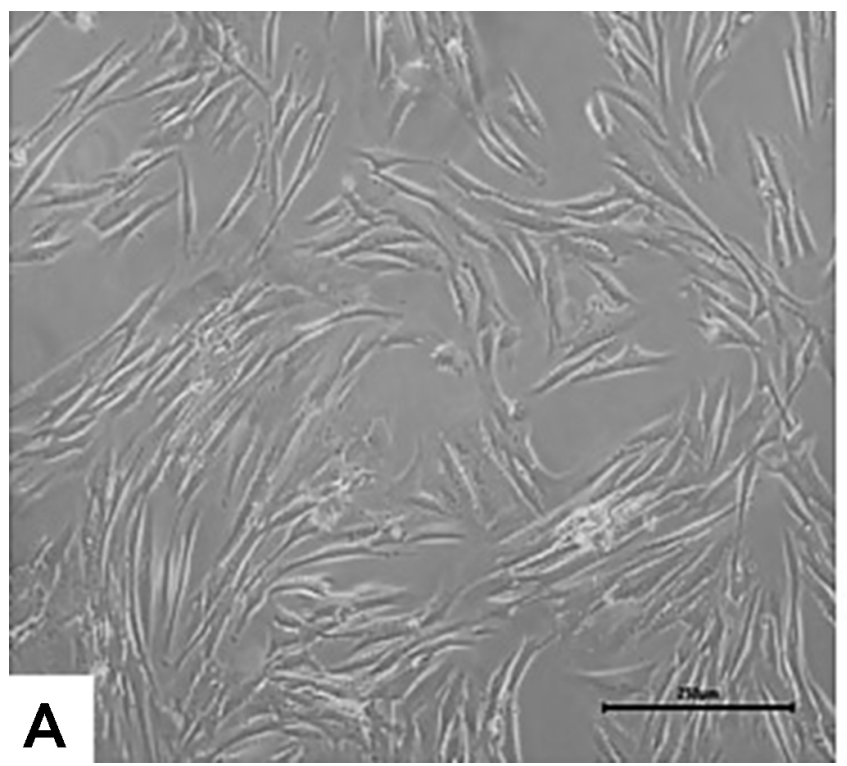

MTT cell proliferation assay. In the assessment of cell proliferation through the MTT cell metabolism assay, all cell samples had an increase in cell proliferation throughout their following passages. A statistically significant difference was observed between the proliferation rate of sample 2 compared to the rest of the samples after $72 \mathrm{~h}, 96 \mathrm{~h}$ and $120 \mathrm{~h}$ $(\mathrm{p}<0.05) *$ (Fig. 2).

Immunophenotyping. The phenotype analysis by immunocitofluorescence assay of isolated cells, showed the presence of surface markers as CD40, CD44 and CD105 (Fig. 3). Likewise, in RT-PCR assay the expression of CD14, CD44 and STRO -1 markers (Fig. 4) was observed. A summary of the results obtained is showed in Table III (Kanafi et al., 2013).

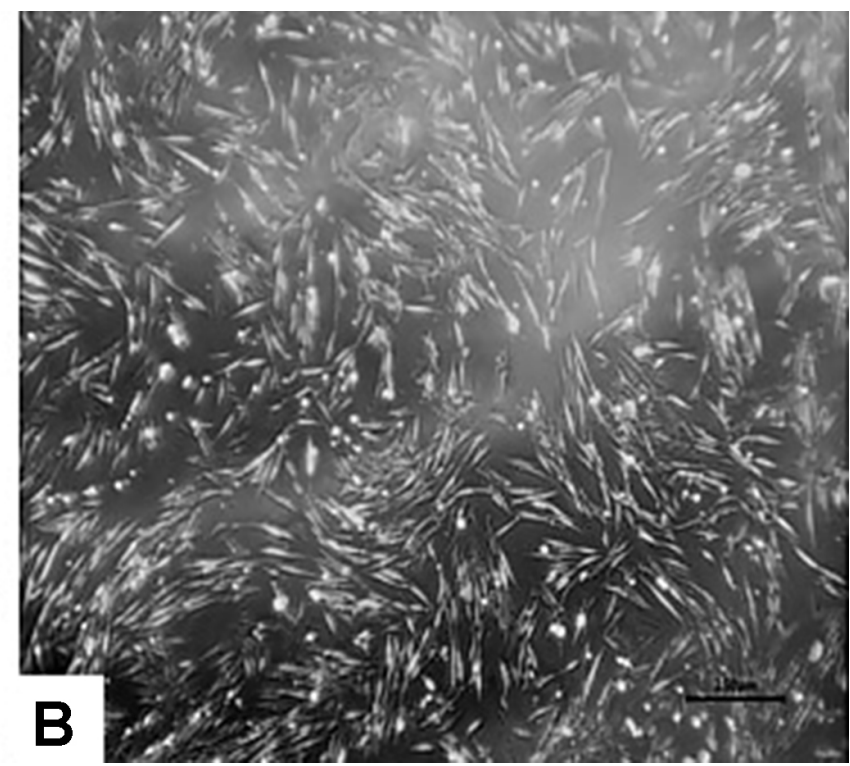

Fig. 1. Cell culture. (A) Fibroblast-like morphology of Human Dental Pulp Cells after 10 days of cell culture (10X). (B) Confluence $>80 \%$ of Human Dental Pulp Cells after 28 days of cell culture (4X). Bar= 250mm.

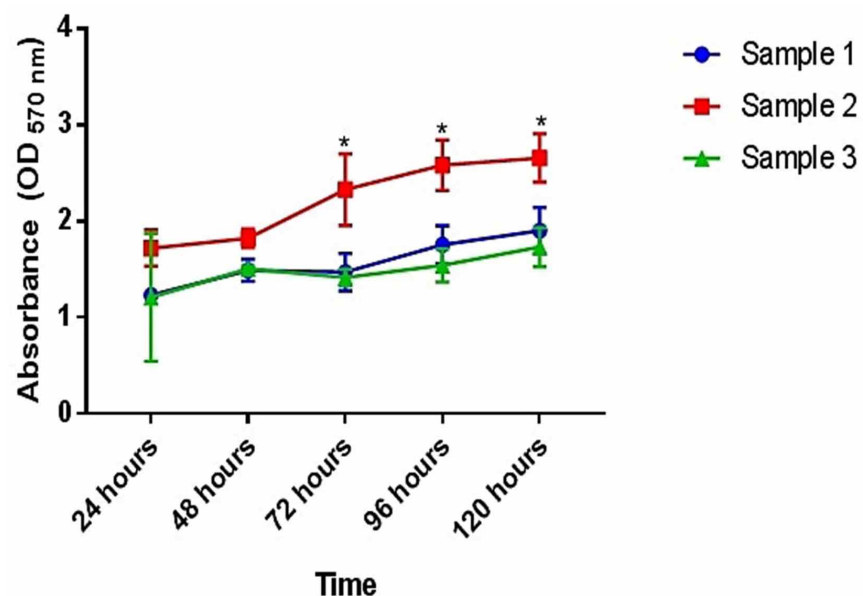

Fig. 2. MTT assay to evaluate the cell proliferation of three dental pulp cell samples with $24 \mathrm{~h}, 48 \mathrm{~h}$, $72 \mathrm{~h}, 96 \mathrm{~h}$ and $120 \mathrm{~h}$ analyzed on a $570 \mathrm{~nm}$ plate reader. Statistically significant difference was observed in sample 2 with respect to 1 and 3 after $72 \mathrm{~h}(\mathrm{p}<0.05) *$. The counts were made in triplicate and the standard deviation is shown. 


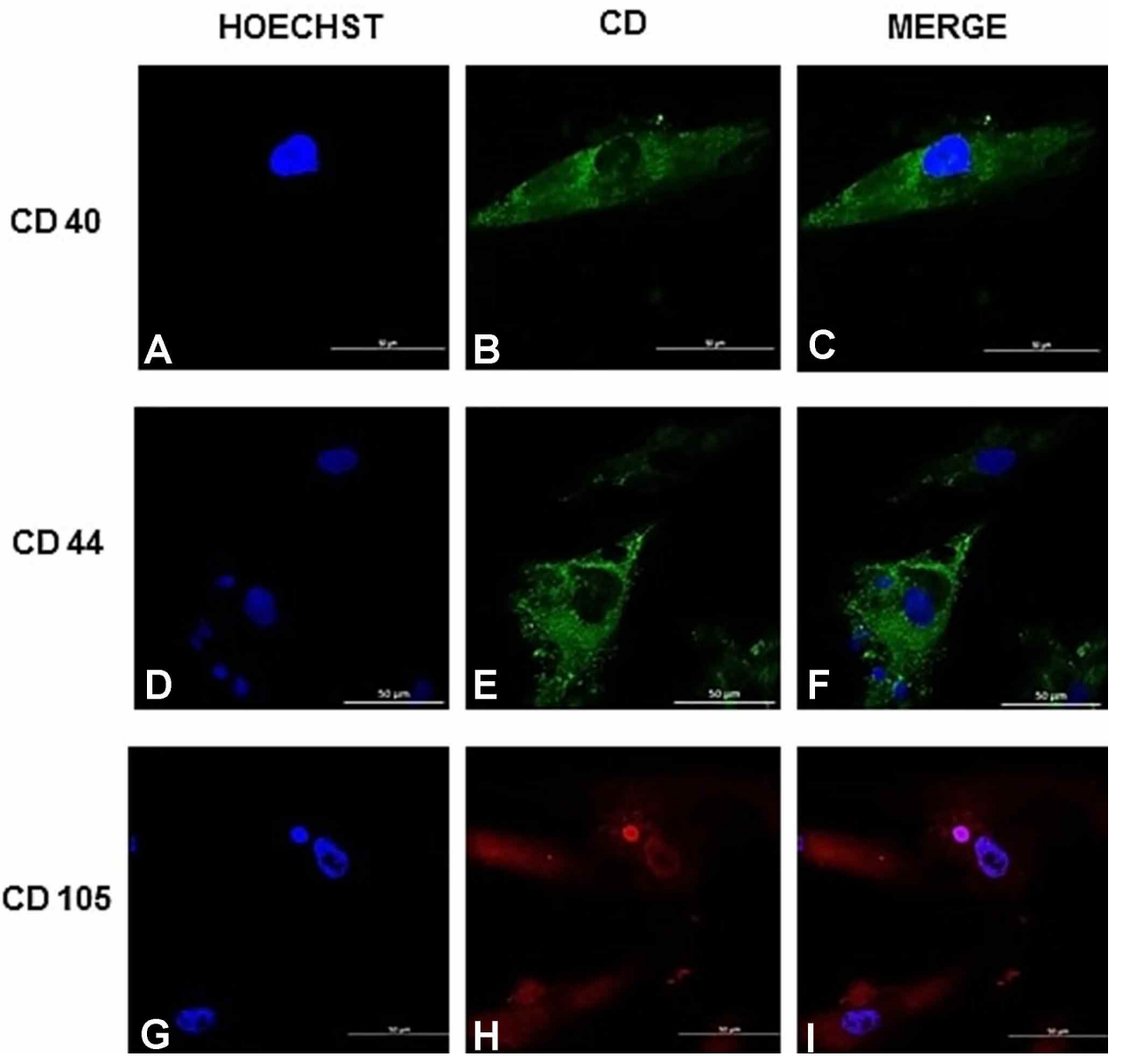

Fig. 3. Immunofluorescence staining of surface markers CD40, CD44 and CD105 demonstrating the pluripotential phenotype of hDPSCs by confocal microscopy. Nuclear counterstaining with Hoechst (A, D, G). (B) CD40. (E) CD44. (H) CD105 [Endoglin]. (C, F, I) Merge. Bar= $50 \mu \mathrm{m}$.

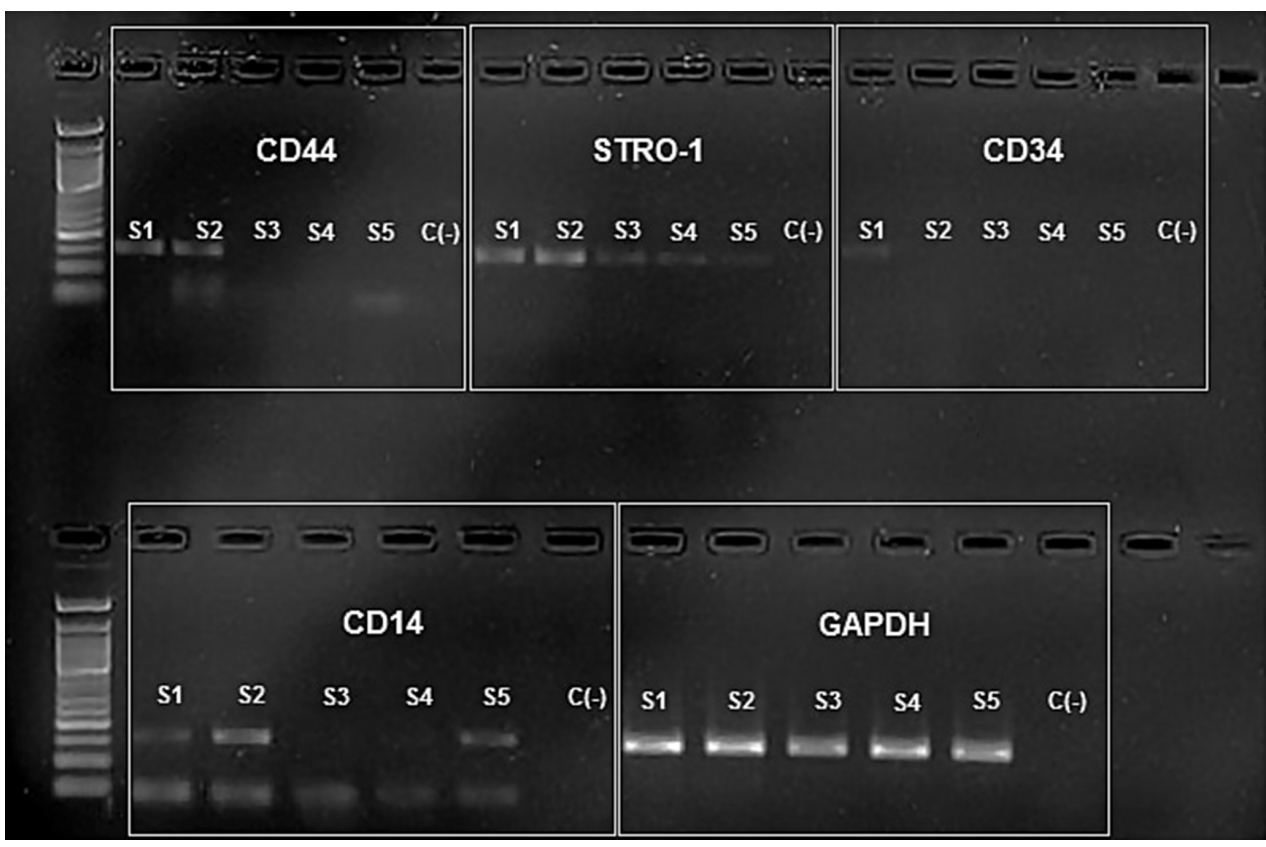

Fig. 4. RT-PCR. CDs expression analysis of pluripotenciality markers (CD44, STRO-1, CD34, CD14) in samples of hDPSCs. GAPDH was used as a housekeeping gene. $\mathrm{S}=$ Samples. $C(-)=$ Negative control. 
Dental enamel proteins detection in differentiated cells. After the cell stimulation process of hDPSCs cultured in pre-treated plates with the EMG from pig's skin, that contain extracellular matrix or collagen type I from rat tail tendon, an immunodetection protocol was carried out in order to detect the expression of enamel proteins. The samples processed for analysis with confocal microscopy showed

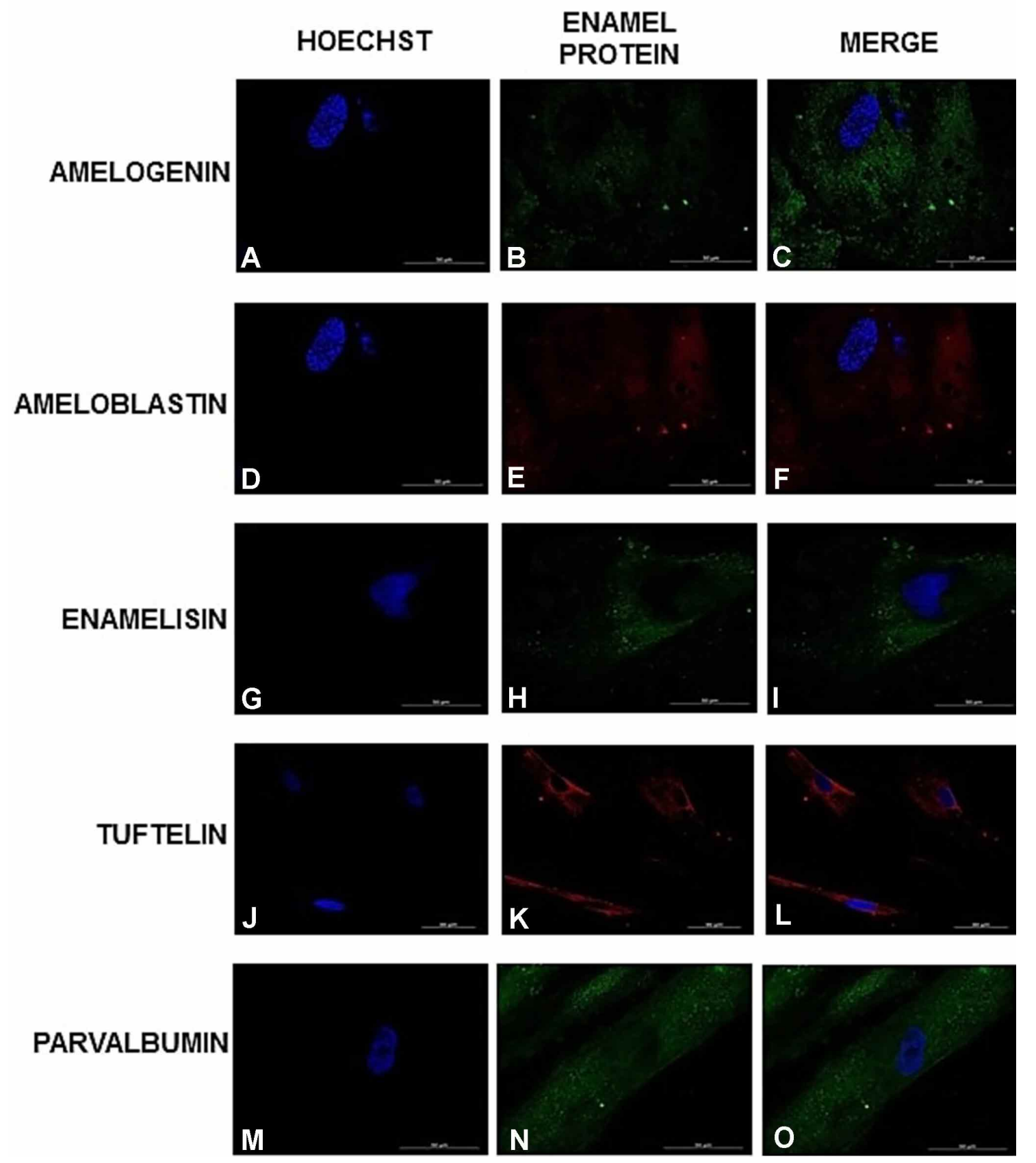

Fig. 5. Immunofluorescence labeling and analysis by confocal microscopy of dental enamel proteins: Amelogenin, Ameloblastin, Enamelisin, Tuftelin and Parvalbumin in hDPSCs treated with pig skin extracellular matrix gel. (A, D, G, J, M) Cell nuclear counterstaining with Hoechst. (B) Detection of Amelogenin with Alexa Fluor® 488. (E) Detection of Ameloblastin with Alexa Fluor ${ }^{\circledR}$ 594. (H) Detection of Enamelisin with Alexa Fluor ${ }^{\circledR}$ 488. (K) Detection of Tuftelin with Alexa Fluor 594. (N) Detection of Parvalbumin with Alexa Fluor ${ }^{\circledR}$ 488. (C, F, I, L, O) Merge, staining Antibody-Hoechst. Bar= 50mm. 


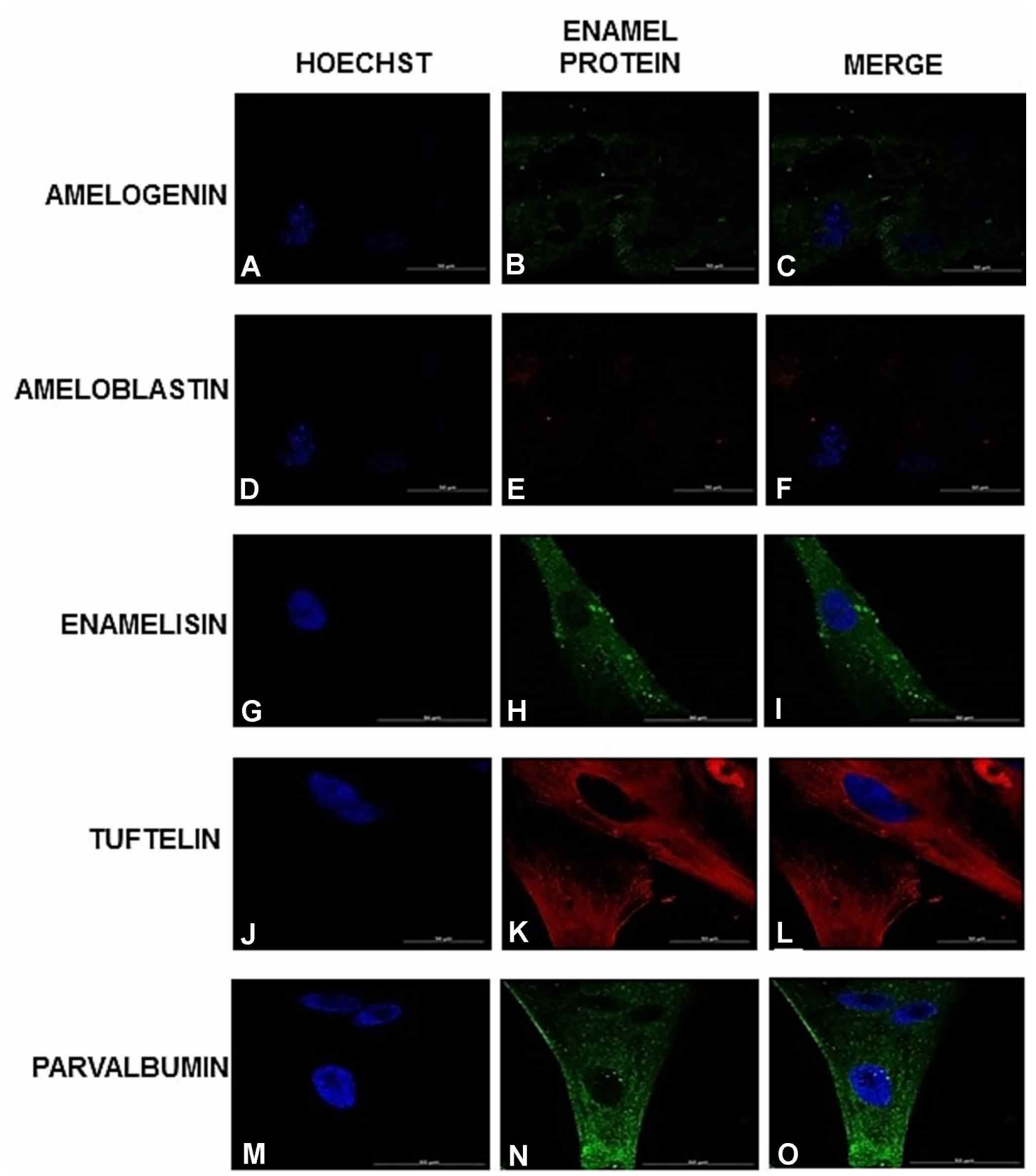

Fig. 6. Immunocytofluorescence labeling and analysis by confocal microscopy of dental enamel proteins:Amelogenin, Ameloblastin, Enamelisin, Tuftelin and Parvalbumin in hDPSCs treated with rat tail tendon extracellular matrix gel. (A, D, G, J, M) Cell nuclear counterstaining with Hoechst. (B) Detection of Amelogenin with Alexa Fluor ${ }^{\circledR} 488$. (E) Detection of Ameloblastin with Alexa Fluor ${ }^{\circledR}$ 594. (H) Detection of Enamelisin with Alexa Fluor ${ }^{\circledR} 488$. (K) Detection of Tuftelin with Alexa Fluor ${ }^{\circledR}$ 594. (N) Detection of Parvalbumin with Alexa Fluor ${ }^{\circledR}$ 488. (C, F, I, L, O) Merge, staining Antibody-Hoechst. Bar $=50 \mu \mathrm{m}$.

\begin{tabular}{ccccccc}
\hline CDs & $\begin{array}{c}\text { Expected Marker } \\
\text { (Kanafi } \text { et al., 2013) }\end{array}$ & S1 & S2 & S3 & S4 & S5 \\
\hline CD14 & - & + & + & + & + & + \\
CD34 & - & + & - & - & - & - \\
CD44 & + & + & + & + & - & + \\
STRO-1 & + & + & + & + & + & + \\
\hline
\end{tabular}

Table III. Results of the expression of mesenchymal CDs genes in human dental pulp stem cell (hDPSCs) by RT-PCR. (+) Positive marker for hDPSCs. (-) Negative marker for hDPSCs. (S) Sample. 
SALAZAR-DE SANTIAGO, A.; AVELAR-GONZÁLEZ, F. J.; DÍAZ, J. M.; CAMPOS-NAVARRO, P. M.; FLORES-VILLALPADO, E. M.; HERNÁNDEZ-CUÉLLAR, E. E. \& GUERRERO-BARRERA, A. L. Expression of enamel proteins in human dental pulp stem cells by the effect of extracellular matrix. Int. J.Morphol., 38(6):1742-1750, 2020.

\section{DISCUSSION}

Tissue engineering has progressed significantly in the last decade, as several investigations have focused their efforts on the development and repair of organs and tissues with the use of stem cells, cells scaffolds, growth factors, and molecules implicated in the process of differentiation (Egusa et al., 2012). Recently, due to the capacity of MSCs derived from dental tissues for self-renewal, differentiation, and plasticity, they have generated interest for their role in the reconstruction and regeneration of hard and soft tissues (Nakashima \& Hayashi, 2019). In the present work, primary cell cultures of human dental pulp from third molars surgically removed were used, since they are the last dental organs to erupt, presenting less embryonic and dental development (Sedgley \& Botero, 2012). The cell viability evaluated by the MTT assay demonstrated stable and upward behavior necessary for subsequent experiments (Benício et $a l$.). The morphological characteristics of the spindle and fibroblast shape, as well as its mesenchymal and pluripotential nature, are demonstrated by the expression of CD14, CD40, CD44, CD105, and STRO-1, coinciding with the results of other authors (Sun et al., 2014; Avinash et al., 2017). The loss of dental organs forces the dentist to replace them to return the functionality to the oral cavity. Ideally, it would be for an implant of non-embryonic cells with the same germinal properties that originate the components of a functional tooth (Volponi et al., 2010). With the use of hDPSCs, the regeneration of the dentin-pulp complex and functional roots has been achieved (Benício et al.). However, regeneration of tooth enamel has been a major challenge, even its reshaping or endogenous regeneration is not feasible, as it is formed before tooth eruption (Huang, 2011). However, mechanisms have been seeked to obtain it at a stage after the dentinogenic process, using human fetuses and rat models (Morotomi et al., 2005; Yan et al., 2006) and it has been reported that the only producing sources would be those derived of the same embryonic origin as Hertwing's epithelial sheath and Malassez's epithelial cells and from alternative sources such as bone marrow, embryonic cells, induced pluripotent stem cells (IPSCs) and skin epithelial, which require differentiation by stimuli with growth factors, cytokines (TGF, FGF, Wnts and BMP) and extracellular matrix compounds generated by the epithelium and the mesenchyme (Hyun et al., 2019). In the present work and using tissue engineering techniques, the pluripotential capacity of hDPSCs to express tooth enamel proteins that participate in amelogenesis was demonstrated (CamposNavarro et al.) as amelogenin, ameloblastine, tuftelin, enamelisin and parvalbumin by induction generated by natural scaffolds made from pigskin glue and rat tail tendon (Maurer et al., 2018; Davison-Kotler et al., 2019), which according to the results reported by Yang \& Shu, its composition is $90 \%$ to $95 \%$ of type I collagen. This is based on the knowledge that the proteins and growth factors of the EMC have a determining role in the processes of cell maintenance and differentiation (Fukumoto \& Yamada; Ravindran et al., 2013), as occurs during dental development and morphogenesis, where the sequential interactions generated by the mesenchymal cells of the neural crest and those of the ectoderm allow dentinogenesis and induction of the formation of dental enamel and dentin by the secretion of their EMC-forming basement membranes composed of type I and IV collagen, laminin, fibronectin, decorin, integrin, perlecan, and nidogen, allowing their proliferation and maintenance of phenotypes of cell differentiation (He et al., 2010). Therefore, the results are promising for tissue engineering to analyze the biology of stem cells derived from dental tissues and to explore the properties of the ECM used as a scaffold with biocompatibility and low immunogenicity properties in contact with the cells.

\section{ACKNOWLEDGEMENTS}

We are grateful to Adriana Cecilia Moreno Flores and Fabiola Galindo Guerrero of the UAA and the Laboratory of Molecular Medicine of the Health Sciences Area of the UAZ for the technical support provided.

\section{SALAZAR-DE SANTIAGO, A.; AVELAR- GONZÁLEZ, F. J.; DÍAZ, J. M.; CAMPOS-NAVARRO, P. M.; FLORES-VILLALPADO, E. M.; HERNÁNDEZ- CUÉLLAR, E. E. \& GUERRERO-BARRERA, A. L. Expresión de proteínas de esmalte en células madre de pul- pa dental humana por el efecto de matriz extracelular. Int. J.Morphol., 38(6):1742-1750, 2020.}

RESUMEN: Las células madre mesenquimales están presentes en los tejidos adultos como la pulpa dental humana. Son pluripotentes y pueden diferenciarse en varios tipos de células especializadas in vitro a través de estímulos adecuados. Los ameloblastos producen esmalte dental humano sólo durante el desarrollo embrionario antes de la erupción dental, por lo que no es posible su regeneración endógena. Varios esfuerzos se han orientado a generar sustitutos naturales o artificiales de esmalte dental con propiedades similares a los componentes específicos de este tejido. El propósito de este estudio fue inducir células madre de pulpa dental humana para producir proteínas del esmalte dental a través del estímulo de matriz extracelular derivada del tendón de la cola de rata y piel de cerdo. Se establecieron cultivos primarios de células madre de pulpa dental hu- 
mana y se caracterizaron por RT-PCR e inmunofluorescencia utilizando marcadores de células mesenquimales como CD14, CD40, CD44, CD105 y STRO-1. Posteriormente, las células se incubaron con matriz extracelular durante un período de catorce días y se marcaron con anticuerpos específicos para detectar la expresión de proteínas de esmalte dental como amelogenina, ameloblastina, enamelisina, tuftelina y parvalbúmina, las cuales son características del fenotipo de ameloblastos. Este trabajo demostró el efecto positivo que tiene el empleo de la matriz extracelular para inducir la expresión de proteínas de esmalte en las células pluripotenciales de la pulpa dental humana.

PALABRAS CLAVE: Células madre; Pulpa dental; Matriz extracelular; Ingeniería tisular; Esmalte dental.

\section{REFERENCES}

Avinash, K.; Malaippan, S. \& Dooraiswamy, J. N. Methods of isolation and characterization of stem cells from different regions of oral cavity using markers: a systematic review. Int. J. Stem Cells, 10(1):12-20, 2017.

Benício, D. F. A.; Pereira, L. O.; Silva, I. C. R.; Azevedo, R. B. \& Bezerra, A. C. B. Culture of human dental pulp cells at variable times posttooth extraction. Braz. Oral Res., 32:e003, 2018.

Bonato, L. S.; Sant'Anna, F. M. \& Pranke, P. Isolation, immunophenotypic characterization and pluripotency of dental pulp stem cells. Dent. Oral Craniofac. Res., 3(5):1-3, 2017.

Campos-Navarro, P. M.; Avelar-González, F. J.; Gutiérrez-Cantú, F. J.; MarielCárdenas, J.; Martínez-Rider, R. \& Guerrero-Barrera, A. L. Human ameloblastin labeling in fetuses. Wulfenia J., 25(2):170-188, 2018.

Chiego, D. J. Essentials of Oral Histology and Embryology. A Clinical Approach. St. Louis Missouri, Elsevier Mosby, 2014.

Davison-Kotler, E.; Marshall, W. S. \& García-Gareta, E. Sources of collagen for biomaterials in skin wound healing. Bioengineering (Basel), 6(3):56, 2019

Egusa, H.; Sonoyama, W.; Nishimura, M.; Atsuta, I. \& Akiyama, K. Stem cells in dentistry--Part II: Clinical applications. J. Prosthodont. Res., 56(4):229-48, 2012.

Fukumoto, S. \& Yamada, Y. Review: extracellular matrix regulates tooth morphogenesis. Connect. Tissue Res., 46(4-5):220-6, 2005

He, P.; Zhang, Y.; Kim, S. O.; Radlanski, R. J.; Butcher, K.; Schneider, R. A. \& DenBesten, P. K. Ameloblast differentiation in the human developing tooth: effects of extracellular matrice. Matrix Biol., 29(5):411-9, 2010.

Huang, G. T. J. Dental pulp and dentin tissue engineering and regeneration: advancement and challenge. Front. Biosci. (Elite Ed.), 3:788-800, 2011.

Hyun, S. Y.; Mun, S.; Kang, K. J.; Lim, J. C.; Kim, S. Y.; Han, K. \& Jang, Y. J. Amelogenic transcriptome profiling in ameloblast-like cells derived from adult gingival epithelial cells. Sci. Rep., 9(1):3736, 2019.

Kanafi, M. M.; Rajeshwari, Y. B.; Gupta, S.; Dadheech, N.; Nair, P. D.; Gupta, P. K. \& Bhonde, R. R. Transplantation of islet-like cell clusters derived from human dental pulp stem cells restores normoglycemia in diabetic mice. Cytotherapy, 15(10):1228-36, 2013.

Maurer, T.; Stoffel, M. H.; Belyaev, Y.; Stiefel, N. G.; Vidondo, B.; Küker, S., Mogel, H.; Schäfer, B. \& Balmer, J. Structural characterization of four different naturally occurring porcine collagen membranes suitable for medical applications. PLoS One, 13(10):e0205027, 2018.
Morotomi, T.; Kawano, S.; Toyono, T.; Kitamura, C.; Terashita, M.; Uchida, T.; Toyoshima, K. \& Harada, H. In vitro differentiation of dental epithelial progenitor cells through epithelial-mesenchymal interactions. Arch. Oral Biol., 50(8):695-705, 2005.

Nakashima, M. \& Hayashi, Y. Dental Stem Cells. In: Narayan, R. (Ed.). Encyclopedia of Biomedical Engineering. Amsterdam, Elsevier, 2019. pp.554-64.

Núñez-Toldrà, R.; Martínez-Sarrà, E.; Gil-Recio, C.; Carrasco, M. A.; Al Madhoun, A.; Montori, S. \& Atari, M. Dental pulp pluripotent-like stem cells (DPPSC), a new stem cell population with chromosomal stability and osteogenic capacity for biomaterials evaluation. BMC Cell Biol., 18:21, 2017.

Patel, V. B. \& Preedy, V. R. Biomarkers in Bone Disease. New York, Springer, 2017.

Potdar, P. \& Jethmalani, Y. Human dental pulp stem cells: Applications in future regenerative medicine. World J. Stem Cells, 7(5):839-51, 2015.

Ravindran, S.; Huang, C. C. \& George, A. Extracellular matrix of dental pulp stem cells: applications in pulp tissue engineering using somatic MSCs. Front. Physiol., 4:395, 2013.

Sedgley, C. M. \& Botero, T. M. Dental stem cells and their sources. Dent. Clin. North Am., 56(3):549-61, 2012.

Singh, V. K.; Saini, A.; Kalsan, M.; Kumar, N. \& Chandra, R. Describing the stem cell potency: the various methods of functional assessment and In silico diagnostics. Front. Cell Dev. Biol., 4:134, 2016.

Sun, H. H.; Chen, B.; Zhu, Q. L.; Kong, H.; Li, Q. H.; Gao, L. N.; Xiao, M.; Chen, F. M. \& Yu, Q. Investigation of dental pulp stem cells isolated from discarded human teeth extracted due to aggressive periodontitis. Biomaterials, 35(35):9459-72, 2014.

Volponi, A. A.; Pang, Y. \& Sharpe, P. T. Stem cell-based biological tooth repair and regeneration. Trends Cell Biol., 20-206(12-6):715-22, 2010.

Yan, Q.; Zhang, Y.; Li, W. \& DenBesten, P. K. Differentiation of human ameloblast-lineage cells in vitro. Eur. J. Oral Sci., 114 Suppl. 1:154-8, 2006

Yang, H. \& Shu, Z. The extraction of collagen protein from pigskin. $J$. Chem. Pharm. Res., 6(2):683-7, 2014.

Corresponding author:

Alma Lilian Guerrero-Barrera

Laboratorio de Biología Celular y Tisular

Edificio 203

Avenida Universidad 940

Universidad Autónoma de Aguascalientes

CP 20131

Aguascalientes, Ags.

MÉXICO

Email: alguerre@correo.uaa.mx

Received: 17-06-2020

Accepted: $31-08-2020$ 